\title{
Effects of Nordmøre-grid angles, profiles and other industry-developed modifications on catches in an Australian penaeid-trawl fishery
}

\section{Efectos de ángulos y perfiles de las rejillas Nordmøre, y otras modificaciones desarrolladas por la industria, sobre las capturas de una pesquería australiana de peneidos}

\author{
Matt K. Broadhurst* \\ Damian J. Young \\ Cristiana Damiano \\ NSW Fisheries Conservation Technology Unit \\ National Marine Science Centre \\ PO Box J321 \\ Coffs Harbour, NSW 2450 \\ Australia \\ *E-mail: mbroadhurst@nmsc.edu.au \\ Recibido en julio de 2003; aceptado en septiembre de 2003
}

\begin{abstract}
In response to claims that conventional Nordmøre-grids used in the Clarence River penaeid-trawl fishery were occasionally being fouled or blocked during fishing, two experiments were done to examine the utility of modified grids with different installation angles, sizes and profiles, and alternative industry-developed, behavioral-type bycatch reduction devices (BRDs). In experiment 1, a conventional Nordmøre-grid $\left(600 \mathrm{~mm}\right.$ in length, installed at $\left.45^{\circ}\right)$ was compared against a longer grid (1200 mm in length, installed at $21^{\circ}$ ) and two locally-developed, behavioral-type BRDs. While slightly more difficult to operate than the conventional design, the longer Nordmøre-grid retained similar quantities of penaeids and bycatch; in contrast, both behavioraltype BRDs retained significantly (up to five times) more bycatch and were considered ineffective for use in this fishery. In experiment 2, the conventional Nordmøre-grid was tested against three modified Nordmøre-grids, including a 600-mm-long grid with a curved profile and installed at $45^{\circ}$, and two grids, both $900 \mathrm{~mm}$ in length and installed at $28^{\circ}$, but with flat and curved profiles. Only the curved 900-mm Nordmøre-grid caught significantly fewer penaeids and bycatch, although both of the curvedprofile grids appeared to facilitate the release of debris from the trawl. The results are discussed in terms of fishery-specific factors that probably contributed towards the performances of the various BRDs.
\end{abstract}

Key words: bycatch reduction, shrimp, prawn, selectivity, Nordmøre-grid.

\section{Resumen}

En respuesta al reclamo de que las rejillas Nordmøre convencionales usadas en la pesquería de peneidos en el Río Clarence (NSW, Australia) se obstruían o bloqueaban durante las operaciones de pesca, se llevaron a cabo dos experimentos para examinar la eficacia de rejillas modificadas (con diferentes ángulos de instalación, tamaños y perfiles) y de dispositivos de tipo conductual para la reducción de la fauna acompañante desarrollados por la industria. En el experimento 1, se comparó una rejilla Nordmøre convencional $\left(600 \mathrm{~mm}\right.$ de longitud, instalada a $\left.45^{\circ}\right)$ con una rejilla Nordmøre más larga $\left(1200 \mathrm{~mm}\right.$ de longitud, instalada a $\left.21^{\circ}\right)$ y con dos dispositivos conductuales desarrollados localmente. Aunque ligeramente más difícil de operar que la rejilla Nordmøre convencional, la rejilla más larga retuvo cantidades similares de peneidos y fauna acompañante; sin embargo, los dos dispositivos conductuales retuvieron considerablemente más fauna acompañante (hasta cinco veces más), por lo que fueron considerados ineficaces para este tipo de pesquería. En el experimento 2, se comparó la rejilla Nordmøre convencional con tres rejillas Nordmøre modificadas: la primera de $600 \mathrm{~mm}$ de longitud con perfil curvo e instalada a $45^{\circ}$, y las otras dos de $900 \mathrm{~mm}$ de longitud e instaladas a $28^{\circ}$, pero una con perfil plano y la otra con perfil curvo. Sólo la rejilla Nordmøre de $900 \mathrm{~mm}$ y perfil curvo capturó significativamente menos peneidos y fauna acompañante; no obstante, ambas rejillas con perfil curvo parecían facilitar la descarga de basura de la red de arrastre. Se discuten los resultados considerando factores específicos de la pesquería que probablemente influyeron en el comportamiento de los diversos dispositivos utilizados.

Palabras clave: reducción de la fauna acompañante, camarón, langostino, selectividad, rejilla Nordmøre. 


\section{Introduction}

The capture and mortality of non-target organisms (termed bycatch) from prawn/shrimp trawling has received substantial attention over the past 20 years (for reviews, see Saila, 1983; Andrew and Pepperell, 1992; Alverson et al., 1994). In most fisheries, the negative perceptions associated with this issue have been mitigated through the legislation of physical modifications to the codends of trawls, collectively termed "bycatch reduction devices" or BRDs (for a review, see Broadhurst, 2000). Inherent variability among the characteristics of different fisheries has resulted in a plethora of BRDs, although all can be classified into two categories. The first includes those designed to mechanically exclude organisms larger than the targeted species, based on differences in their size (e.g., Isaksen et al., 1992; Broadhurst and Kennelly, 1996a); these designs comprise some sort of inclined grid that directs bycatch out of trawls through the bottom or top of the codend. The second category of BRDs have strategically-positioned openings that function by exploiting differences in species' behavior and physiology (e.g., Rulifson et al., 1992; Rogers et al., 1997; Broadhurst et al., 2002a) and are mostly used to exclude fish similar in size or smaller than the targeted species (Broadhurst, 2000).

BRDs from both categories are legislated for use in penaeid-trawl fisheries throughout New South Wales (NSW), Australia. Specifically, a rigid mechanical-type BRD called the Nordmøre-grid (sensu Isaksen et al., 1992) is used in estuaries and is effective in reducing up to $90 \%$ of unwanted bycatch, with no reduction in the catches of the targeted school prawn, Metapenaeus macleayi, or eastern king prawn, Penaeus plebejus (Broadhurst and Kennelly, 1996a). Various behavioral-type BRDs are similarly efficient in reducing the catches of small, unwanted fish from trawlers targeting eastern king prawns and other commercially-important species in oceanic waters (Broadhurst and Kennelly, 1996b; Broadhurst et al., 2002a). These BRDs are simple, involving large rectangular- and triangular-shaped openings or composite panels of square-shaped mesh located in the tops of codends. An important and common factor among these designs is their legislated positioning at less than $1.2 \mathrm{~m}$ anterior to the last row of meshes in the codend. At this location, the displacement of water in front of the catch greatly facilitates the escape of individuals of key fish species, but not the targeted penaeids (Broadhurst et al., 2002a).

There is a facility for the ongoing refinement and testing by commercial fishers of BRDs with the appropriate legislation in NSW. This has occurred across many areas, but particularly in the Clarence River trawl fishery (Broadhurst, 2000). Fishers working in this estuary have reported that, while there are few operational problems with the Nordmøre-grid, occasionally it can be fouled or blocked by organisms and/or weed and debris. Several fishers have addressed this problem by substituting the Nordmøre-grid with locally-designed, behavioral-type BRDs. These designs are similar in concept to those developed in

\section{Introducción}

La captura y mortandad de la fauna incidental en la pesquería de arrastre de camarones y langostinos ha recibido considerable atención durante los últimos 20 años (ver Saila, 1983; Andrew y Pepperell, 1992; Alverson et al., 1994). En la mayoría de las pesquerías, las percepciones negativas asociadas con este problema han sido mitigadas mediante la reglamentación de modificaciones físicas al copo de la red de arrastre, conocidas en general como "dispositivos para la reducción de la fauna acompañante" o BRDs por sus siglas en inglés (ver Broadhurst, 2000). La variabilidad inherente entre las características de diversas pesquerías ha resultado en una gran cantidad de BRDs, aunque todos pueden clasificarse en dos categorías. La primera incluye los BRDs, diseñados para excluir mecánicamente los organismos de mayor tamaño que las especies objetivo, con base en diferencias de talla (e.g., Isaksen et al., 1992; Broadhurst y Kennelly, 1996a); estos diseños comprenden algún tipo de rejilla inclinada que dirije la salida de la fauna acompañante de la red por la parte inferior o superior del copo. La segunda categoría incluye los BRDs de tipo conductual, que tienen aperturas en posiciones estratégicas y funcionan con base en el comportamiento y la fisiología de las especies (e.g., Rulifson et al., 1992; Rogers et al., 1997; Broadhurst et al., 2002a); se utilizan principalmente para excluir peces del mismo tamaño o menores que las especies objetivo (Broadhurst, 2000).

En la reglamentación de la pesquería de peneidos de Nueva Gales del Sur (NSW), Australia, se ha incluido el uso de BRDs de ambas categorías. Específicamente, en los estuarios se utiliza un tipo de BRD rígido de tipo mecánico, llamado rejilla Nordmøre (sensu Isaksen et al., 1992), que reduce eficazmente hasta $90 \%$ de la fauna acompañante sin reducir las capturas de las especies objetivo, los langostinos Metapenaeus macleayi y Penaeus plebejus (Broadhurst y Kennelly, 1996a). Existen varios BRDs de la segunda categoría que también reducen eficientemente las capturas de peces pequeños no deseados en la pesca de P. plebejus y otras especies de importancia comercial en aguas oceánicas (Broadhurst y Kennelly, 1996b; Broadhurst et al., 2002a). Estos BRDs son sencillos e involucran aperturas grandes de forma rectangular y triangular o paños compuestos de malla cuadrada en la parte superior del copo. Un factor importante y común a estos diseños es su posición reglamentaria a menos de $1.2 \mathrm{~m}$ antes de la última hilera de mallas en el copo. En esta posición, el desplazamiento de agua en frente de los organismos capturados facilita la fuga de ciertas especies, pero no de los peneidos (Broadhurst et al., 2002a).

Con una legislación apropiada, en NSW se facilita el mejoramiento y la prueba de BRDs por los pescadores comerciales; esto ha sucedido en varios sitios pero particularmente en la pesca de arrastre en el Río Clarence (Broadhurst, 2000). Los pescadores que trabajan en este estuario han comentado que, aunque existen pocos problemas en la operación de las rejillas Nordmøre, ocasionalmente éstas quedan obstruidas por organismos y/o algas y basura. Para tratar de 
Broadhurst et al.: Effects of Nordmøre-grid angles, profiles and other BRDs

other local (e.g., Broadhurst et al., 2002a) and overseas (e.g., Rulifson et al., 1992; Rogers et al., 1997) fisheries and comprise simple components which are not fouled like inclined grids. Although the use of these new industry-developed BRDs is widespread, no formal information is available on their effectiveness in reducing bycatch in the Clarence River.

The fouling and/or blocking of mechanical-type BRDs during trawling is a problem in several fisheries (e.g., Renaud et al., 1993; Larsen, 1996; Broadhurst et al., 2002b) and is attributed to the grid angle, which typically ranges between $35^{\circ}$ and $50^{\circ}$, but more commonly is $45^{\circ}$ (Christian and Harrington, 1987; Isaksen et al., 1992; Madsen and Hansen, 2001; Broadhurst et al., 2002b). Few published studies have examined the effects on catches associated with lowering the angles of grids and/or altering their profiles. Of the work that has been done, Isaksen et al. (1992) suggested that Nordmøregrids installed in North Sea shrimp, Pandalus borealis, trawls at angles below $35^{\circ}$ and above $50^{\circ}$ had greater shrimp loss and blockage, respectively. More recently, Larsen (1996) suggested that grids installed at angles below $35^{\circ}$ are less likely to be fouled owing to an increase in the movement of water (and therefore catch) through the escape opening. Further, because the dimensions of grids need to correspond to defined codend fishing circumferences (frequently approximated as $0.35 \times$ the mesh opening $x$ the number of meshes in circumference), lower angles require longer grids and therefore greater surface areas, which may facilitate the movement of catch and its separation (Riedel and DeAlteris, 1995).

Given the above, our aims in this paper were to formally compare the relative effectiveness of industry-developed, behavioral-type BRDs and lower angles, larger sizes and different profiles of the Nordmøre-grid on bycatch reduction in the Clarence River penaeid-trawl fishery. These aims were addressed in two experiments. The first involved a comparison of the existing conventional Nordmøre-grid installed at $45^{\circ}$, a long Nordmøre grid installed at $21^{\circ}$ and two locally-developed, behavioral-type BRDs. The second experiment involved testing the same conventional design of Nordmøre-grid against more practical-sized grids (with and without different profiles).

\section{Materials and methods}

The two experiments were done in the Clarence River $\left(29^{\circ} 26^{\prime} \mathrm{S}, 153^{\circ} 22^{\prime}\right.$ E) during February and March 2003 using a chartered commercial penaeid trawler $(10 \mathrm{~m}$ in length). Two Florida Flyer trawls, each with a headline length of $7.32 \mathrm{~m}$, were rigged in a standard twin-gear configuration (one on each side of the vessel) and towed at approximately $1.2 \mathrm{~m} \mathrm{~s}^{-1}$ over sandy bottoms in depths ranging from 2 to $6 \mathrm{~m}$. Both trawls were rigged with zippers (Buraschi S146R, $1.45 \mathrm{~m}$ in length) to facilitate the changing of codends.

All codends comprised two sections (for detailed descriptions on terminology used see Anon, 1978). The posterior section was made from 24-mm (all mesh sizes refer to stretched mesh opening) black knotless polyamide (PA) mesh solucionar este problema se ha sustituido esta rejilla con BRDs de tipo conductual diseñados localmente. Estos diseños son similares a los desarrollados en otras pesquerías locales (e.g., Broadhurst et al., 2002a) y extranjeras (e.g., Rulifson et al., 1992; Rogers et al., 1997), e involucran componentes sencillos que no se obstruyen como las rejillas inclinadas. Aunque es común el uso de estos nuevos BRDs desarrollados por la industria, no hay datos disponibles sobre su eficacia en reducir la captura de fauna acompañante en el Río Clarence.

La obstrucción de BRDs de tipo mecánico durante el arrastre es un problema en varias pesquerías (e.g., Renaud et al., 1993; Larsen, 1996; Broadhurst et al., 2002b) y se atribuye al ángulo de la rejilla, que típicamente varía de $35^{\circ}$ a $50^{\circ}$, pero por lo general es de $45^{\circ}$ (Christian y Harrington, 1987; Isaksen et al., 1992; Madsen y Hansen, 2001; Broadhurst et al., 2002b). Se han publicado pocos trabajos que hayan investigado los efectos en las capturas asociados con la reducción de los ángulos de las rejillas y/o la modificación de sus perfiles. Isaksen et al. (1992) indicaron que las rejillas Nordmøre instaladas en ángulos menores a $35^{\circ}$ y mayores de $50^{\circ}$ en las redes de arrastre para la captura de Pandalus borealis en el Mar del Norte resultaron en mayor pérdida de camarón y obstrucción, respectivamente. Más recientemente, Larsen (1996) mencionó que es menos probable que se obstruyan las rejillas instaladas en ángulos menores a $35^{\circ}$ debido al incremento en el movimiento del agua (y por ende de los organismos capturados) a través de la ventana de escape. Asimismo, en vista de que las dimensiones de las rejillas necesitan corresponder a la circunferencia definida del copo de pesca (frecuentemente aproximada como $0.35 \times$ el tamaño de luz de malla $\times$ el número de mallas en la circunferencia), los ángulos menores requieren rejillas más largas y, por tanto, áreas superficiales mayores que pueden facilitar el movimiento de los organismos capturados y su separación (Riedel y DeAlteris, 1995).

Por lo anterior, el objetivo de este trabajo fue comparar el efecto relativo de los BRDs de tipo conductual desarrollados por la industria, así como de menores ángulos, mayores tamaños y diferentes perfiles de la rejilla Nordmøre sobre la reducción de la fauna acompañante en la pesquería de arrastre de peneidos en el Río Clarence, para lo cual se llevaron a cabo dos experimentos. En el primero se compararon una rejilla Nordmøre convencional instalada a $45^{\circ}$, una rejilla Nordmøre larga instalada a $21^{\circ}$ y dos BRDs conductuales desarrollados localmente. En el segundo se comparó la misma rejilla Nordmøre convencional con tres rejillas de tamaño más práctico (con y sin perfiles diferentes).

\section{Materiales y métodos}

Los dos experimentos se realizaron en el Río Clarence $\left(29^{\circ} 26^{\prime} \mathrm{S}, 153^{\circ} 22^{\prime} \mathrm{E}\right)$ durante febrero y marzo de 2003 a bordo de un barco de arrastre camaronero comercial (10 $\mathrm{m}$ de eslora). Se colocaron dos redes de arrastre tipo Florida Flyer, cada una de $7.32 \mathrm{~m}$ de relinga, en una configuración estándar para pesca en paralelo (una en cada lado del barco) y se arrastraron a 
netting (2.5-mm diameter $[\phi]$ braided twine) hung on the bar (i.e., square-shaped mesh with a bar length of $12 \mathrm{~mm}$ ) and measured 65 and 100 bars in length and circumference, respectively (fig. 1a, b). The anterior section was made from $42-\mathrm{mm}$ green knotted polyethylene (PE) netting (2.5-mm $\phi$ twisted twine), 100 meshes in circumference and contained the various BRDs (see below). Zippers were attached to the leading edge of each anterior section.

\section{Experiment 1: the conventional Nordmøre-grid vs a modified Nordmøre-grid and two behavioral-type BRDs}

Four BRDs were constructed and installed into the anterior codend sections described above. The first and second designs were termed the "600 and 1200 Nordmøre-grids" (fig. 1a, b) and included identical oblique guiding panels located anterior
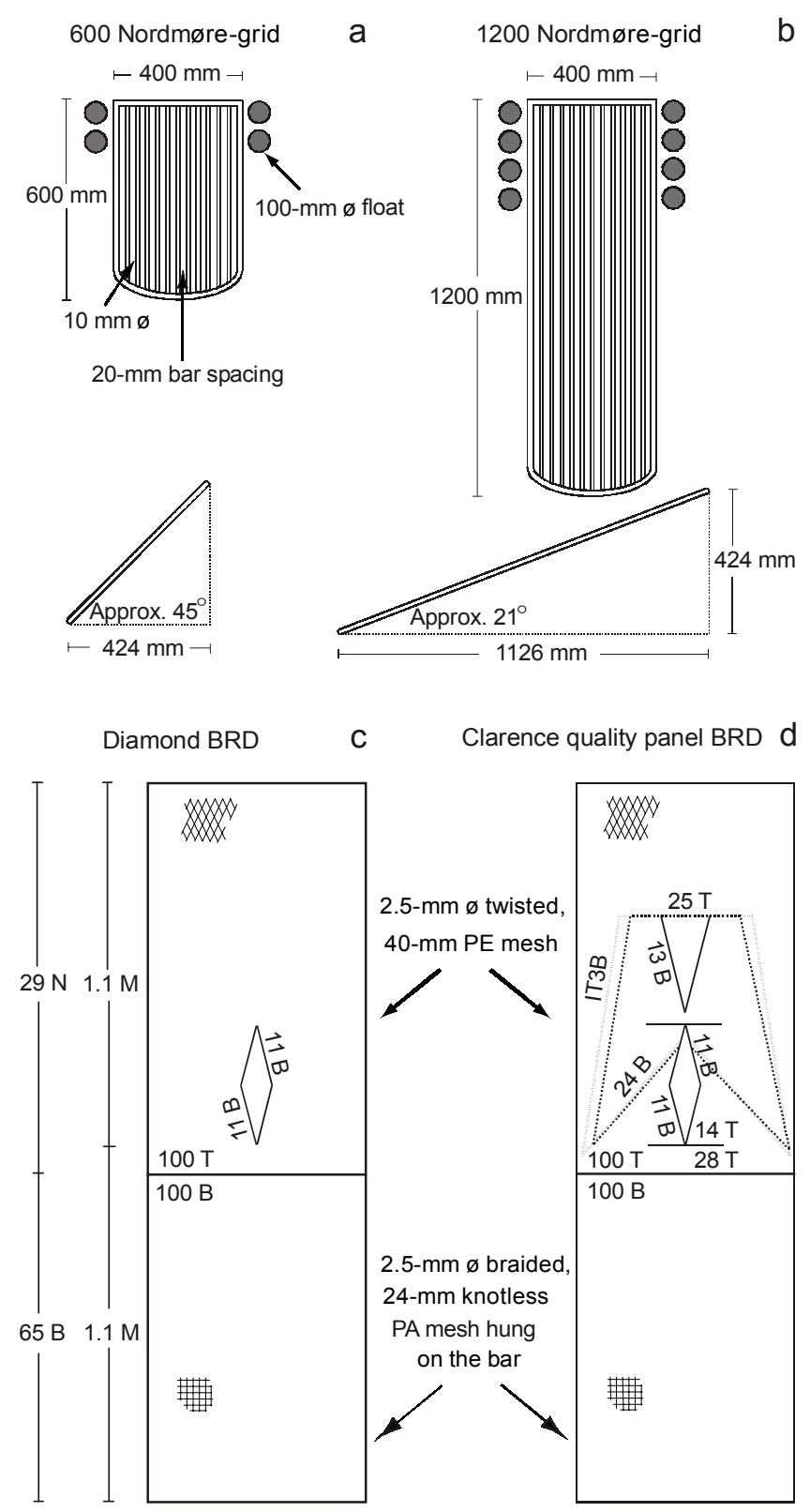

aproximadamente $1.2 \mathrm{~m} \mathrm{~s}^{-1}$ sobre fondos arenosos en profundidades de 2 a $6 \mathrm{~m}$. Ambas redes se equiparon con cremalleras (Buraschi S146R, $1.45 \mathrm{~m}$ de largo) para facilitar el cambio de los copos.

Todos los copos tenían dos secciones (para una descripción detallada de la terminología usada ver Anon, 1978). La sección posterior consistía de paño de poliamida (PA) de $24 \mathrm{~mm}$ de luz de malla estirada, de color negro y sin nudos $(2.5 \mathrm{~mm}$ de diámetro $[\phi]$ de hilo trenzado), colgado de la barra (i.e., malla cuadrada con un largo de barra de $12 \mathrm{~mm}$ ) y de 65 y 100 barras de largo y circunferencia, respectivamente (fig. 1a, b). La sección anterior consistía de paño de polietileno (PE) de $42 \mathrm{~mm}$ de luz de malla estirada, de color verde y con nudos $(2.5 \mathrm{~mm} \phi$ de hilo torsionado), 100 mallas de circunferencia; esta sección contenía los diversos BRDs (ver abajo). Se cosieron cremalleras a las relingas de cada sección anterior.

\section{Experimento 1: rejilla Nordmøre convencional vs rejilla Nordmøre modificada y dos BRDs de tipo conductual}

Se construyeron cuatro BRDs que fueron instalados en las secciones anteriores del copo (ver arriba). Los primeros dos diseños se llamaron "rejillas Nordmøre 600 y 1200" (fig. 1a, b) e incluyeron paños oblicuos de guía idénticos localizados antes de las rejillas construidas de varilla de aluminio de $10 \mathrm{~mm} \phi$ y con un espacio entre barras de $20 \mathrm{~mm}$ (para detalles sobre los paños de guía, ver Broadhurst et al., 1997). La rejilla Nordmøre 600 representó el diseño convencional y consta de una rejilla de $400 \times 600 \mathrm{~mm}$ con un perfil plano que se cosió en el copo a un ángulo de aproximadamente $45^{\circ}$ (para detalles, ver Broadhurst et al., 1997) (fig. 1a). La rejilla Nordmøre 1200, con el mismo perfil que la anterior pero dos veces más larga (i.e., $1200 \mathrm{~mm}$ ), se instaló en el copo con un ángulo de aproximadamente $21^{\circ}$; ésta fue la rejilla más larga de tamaño práctico que se pudo usar en los arrastres. Los BRDs tercero y cuarto fueron de tipo conductual, de los desarrollados por la industria, llamados "diamante" y "paño de calidad Clarence". Ambos BRDs tuvieron una apertura en forma de diamante $(11 \times 11$ mallas) localizada en la parte superior del copo, $1.1 \mathrm{~m}$ enfrente de la última hilera de mallas de la sección posterior (fig. 1c, d). El BRD de paño de calidad Clarence tuvo una segunda apertura triangular (13 mallas de largo) localizada enfrente de la apertura de diamante y un paño de guía oblicuo en forma de cuña cosida de arriba a abajo del copo, acabando inmediatamente debajo de la apertura en forma de diamante (fig. 1d). Según la hipótesis de los pescadores comerciales, este paño de guía oblicuo dirige a todos los organismos hacia la parte inferior del copo y crea un área de flujo reducido que

Figure 1. Two-dimensional representation of the (a) conventionally-used 600 and (b) 1200 Nordmøre-grids, and (c) diamond and (d) Clarence quality panel BRDs.

Figura 1. Representación bidimensional de las rejillas Nordmøre 600 (a) y 1200 (b), así como de los BRDs de diamante (c) y paño de calidad Clarence $(\mathbf{d})$. 
Broadhurst et al.: Effects of Nordmøre-grid angles, profiles and other BRDs

to aluminum grids constructed from $10-\mathrm{mm} \phi$ aluminum rod and with a bar spacing of $20 \mathrm{~mm}$ (see Broadhurst et al., 1997, for details of the guiding panels). The 600 Nordmøre-grid represented the conventional design and comprised a grid $(400 \times 600 \mathrm{~mm})$ with a flat profile, sewn into the codend at an angle of approximately $45^{\circ}$ (for details, see Broadhurst et al., 1997) (fig. 1a). The 1200 Nordmøre-grid had the same profile, but was twice as long as the 600 Nordmøre-grid and sewn into the codend at an angle of approximately $21^{\circ}$ (fig. 1b). This was the longest, practical-sized grid that could be used in the trawls. The third and fourth BRDs were industry-developed, behavioral-type designs, termed the "diamond" and "Clarence quality panel". Both BRDs had a diamond-shaped opening $(11 \times 11$ bars $)$ located on the top of the codend, $1.1 \mathrm{~m}$ in front of the last row of meshes in the posterior section (fig. 1c, d). The Clarence quality panel BRD had a second triangular opening (13 bars in length) located in front of the diamond opening and an oblique, wedge-shaped guiding panel sewn from the top of the codend to the bottom, terminating immediately below the diamond-shaped opening (fig. 1d). Commercial fishers hypothesized that this oblique guiding panel directed all organisms to the bottom of the codend and created an area of reduced flow that allowed fish to maintain position in the vicinity of the diamond and triangular openings, thereby increasing their probability of escape.

The 1200 Nordmøre-grid, diamond and Clarence quality panel BRDs were compared against the conventional 600 Nordmøre-grid in independent, paired hauls (using the twinrigged trawls). The position and order of each codend was determined randomly and used in normal commercial hauls of 20-min duration between 0700 and $1500 \mathrm{~h}$ each day. Two replicate hauls of each treatment BRD against the 600 Nordmøre-grid were done on each day, providing a total of 10 replicate hauls for each pair over 5 days.

\section{Experiment 2: the conventional Nordmøre-grid vs three modified Nordmøre-grids}

Three modified designs of Nordmøre-grid, with different profiles and angles, were constructed and compared to the conventional 600 Nordmøre-grid (fig. 2). Like those tested in experiment 1 , all grids were made from $10-\mathrm{mm} \phi$ aluminum rod and with a bar spacing of $20 \mathrm{~mm}$. The first modified grid was termed the "curved 600 Nordmøre-grid" and contained bars that had a flat profile throughout their lower $70 \%$ and an elevated and curved (radius of $50 \mathrm{~mm}$ ) profile through their upper $30 \%$ (figs. $2 \mathrm{a}, 3$ ). The upper curved section of the grid was designed to facilitate the removal of objects from the codend by preventing them from fouling across the upper frame of the grid. Like the 600 Nordmøre-grid, this grid was sewn into the codend at approximately $45^{\circ}$. The "900 and curved 900 Nordmøre-grids" were similar to the 600 and curved 600 Nordmøre-grids described above, but longer (i.e., $900 \mathrm{~mm}$ ) and sewn into the codend at approximately $28^{\circ}$ (fig. 2b, c). As in experiment 1 , these three modified permite a los peces mantener una posición alrededor de las aperturas en forma de diamante y triángulo, y así aumentar la posibilidad de escape.

Se compararon la rejilla Nordmøre 1200, el BRD de diamante y el de paño de calidad Clarence con la rejilla Nordmøre 600 convencional en arrastres paralelos independientes (utilizando las dos redes). El orden y la posición de cada copo fueron determinados al azar y utilizados en arrastres comerciales normales de $20 \mathrm{~min}$ de duración entre las $0700 \mathrm{y}$ $1500 \mathrm{~h}$ todos los días. Cada día se realizaron dos arrastres con cada BRD experimental contra la rejilla Nordmøre 600, para un total de 10 réplicas para cada par en 5 días.

\section{Experimento 2: rejilla Nordmøre convencional vs. tres rejillas Nordmøre modificadas}

Se construyeron tres diseños modificados de la rejilla Nordmøre, con diferentes perfiles y ángulos, y se compararon con la rejilla Nordmøre 600 convencional (fig. 2). Al igual que las probadas en el experimento 1, todas las rejillas fueron construidas de varilla de aluminio de $10 \mathrm{~mm} \phi$ con un espacio entre barras de $20 \mathrm{~mm}$. La primera rejilla modificada se llamó "rejilla Nordmøre 600 curva", con barras de perfil plano en $70 \%$ de su parte inferior y de perfil elevado y curvo (radio de $50 \mathrm{~mm}$ ) en $30 \%$ de su parte superior (figs. 2a, 3). La parte superior curvada de la rejilla se diseñó para facilitar la extracción de objetos del copo, impidiendo que éstos obstruyeran el marco superior de la rejilla. Al igual que la rejilla Nordmøre 600 , ésta se cosió en el copo a un ángulo de aproximadamente $45^{\circ}$. Las otras dos rejillas modificadas, llamadas "rejillas Nordmøre 900 y 900 curva", fueron similares a las rejillas 600 y 600 curva ya descritas, pero más largas (i.e., $900 \mathrm{~mm}$ ) e instaladas en el copo a aproximadamente $28^{\circ}$ (fig. 2b, c). Estas tres rejillas modificadas se compararon con la rejilla Nordmøre 600 convencional en arrastres paralelos independientes. Cada día se realizaron dos arrastres de cada rejilla modificada y de la convencional, para un total de 14 réplicas en 7 días.

\section{Datos obtenidos y análisis estadísticos}

Los datos recolectados de todos los arrastres fueron: el número y peso del total de peneidos; los números y pesos de los langostinos Metapenaeus macleayi y Penaeus plebejus, así como una submuestra (aproximadamente 100 individuos por arrastre) de la longitud del caparazón (CL, redondeado a $1 \mathrm{~mm}$ ) de $M$. macleayi; el número y peso de la fauna acompañante; y el número de peces de cada especie de importancia comercial y/o recreacional y su longitud furcal (FL, redondeado a los $5 \mathrm{~mm}$ ). Cuando habían suficientes datos para variables (i.e., por lo menos un individuo en cada una de los 8 arrastres réplica), éstos se analizaron con pruebas $t$ pareadas de dos colas $(P \leq 0.05)$. En el experimento 1, para tener una mayor serie de datos, se combinaron las capturas de las tres especies de peces clave: Acantopagrus australis, Gerres subfasciatus y Herklotsichthys castelnaui. Para examinar la 
Curved 600 Nordmøre-grid a
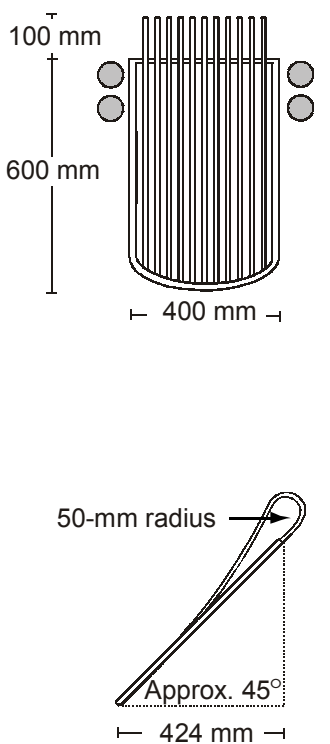

900 Nordmøre-grid b

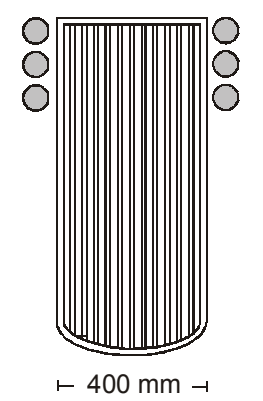

$\vdash 400 \mathrm{~mm} \dashv$

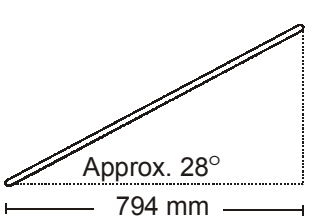

Curved 900 Nordmøre-grid c
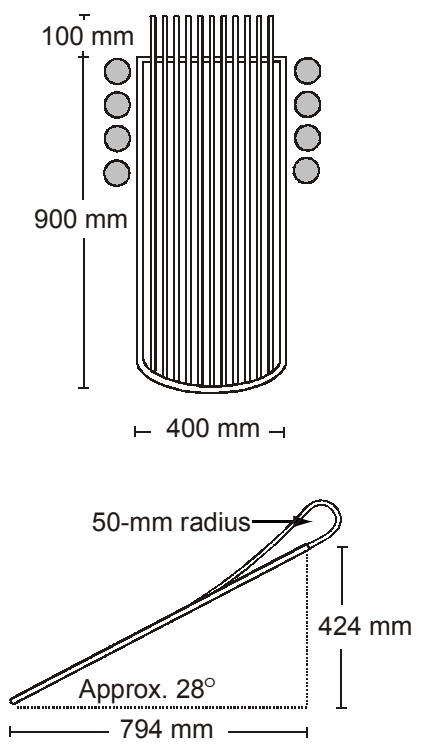

Figure 2. Two-dimensional representation of the (a) curved 600, (b) 900, and (c) curved 900 Nordmøre-grids. Figura 2. Representación bidimensional de las rejillas Nordmøre 600 curva (a), 900 (b), y 900 curva (c).

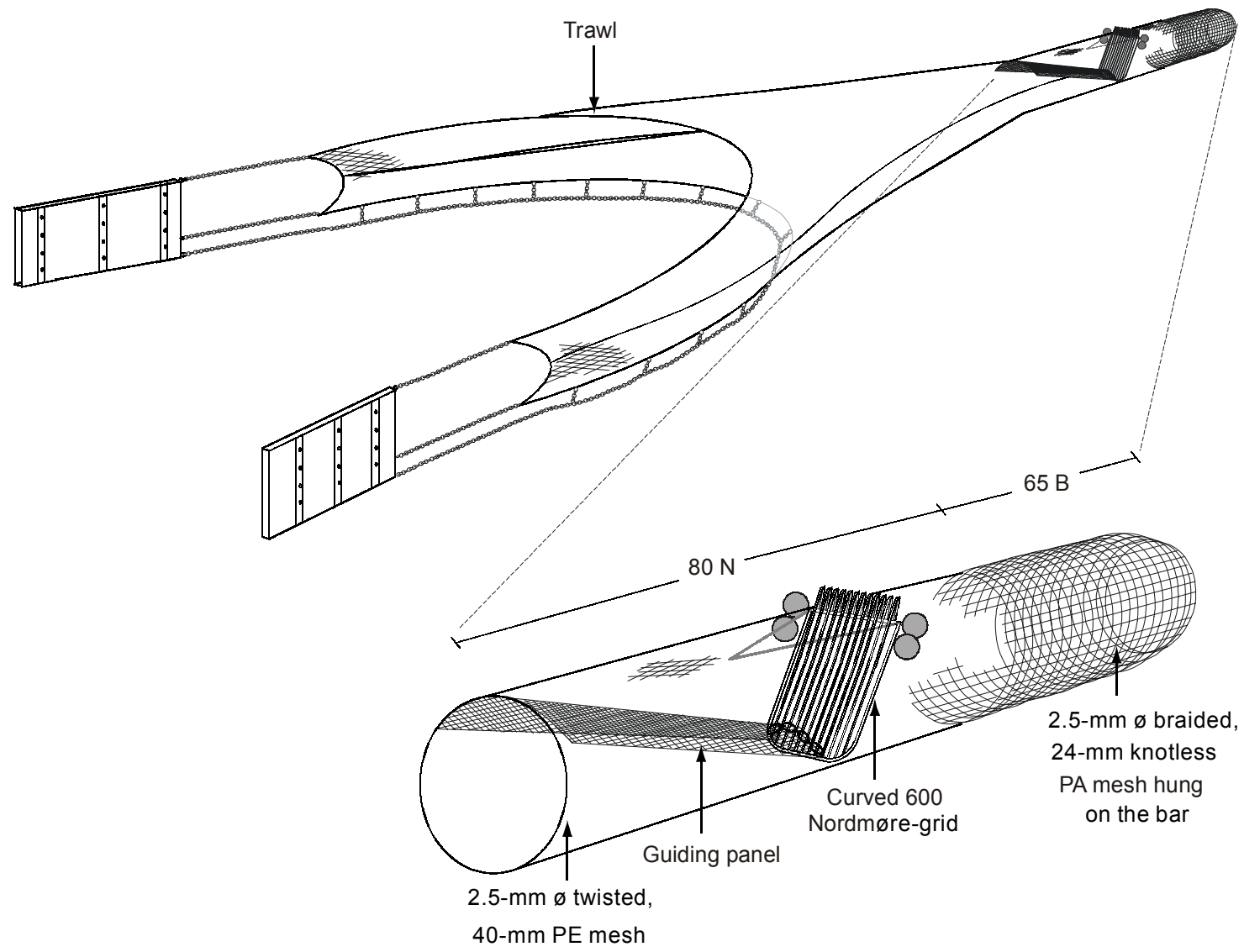

Figure 3. Three-dimensional representation of the trawl and codend containing the curved 600 Nordmøre-grid. Figura 3. Representación tridimensional de la red de arrastre y el copo con la rejilla Nordmøre 600 curva. 
Nordmøre-grids were compared against the 600 Nordmøregrid in independent, paired hauls. Two replicate tows of each modified grid and the 600 Nordmøre-grid were done on each day, providing a total of 14 replicate hauls over 7 days.

\section{Data collected and statistical analyses}

The data collected from all hauls included: the number and weight of total penaeids; the numbers and weights of school and eastern king prawns and a subsample (approximately 100 individuals per tow) of the carapace lengths ( $\mathrm{CL}$ to the nearest $1 \mathrm{~mm}$ ) of school prawns; the number and weight of bycatch; and the numbers of all commercially- and/or recreationallyimportant fish and their fork lengths (FL, to the nearest $5 \mathrm{~mm}$ ). Where there were sufficient data for variables (defined as at least one individual in each of 8 replicate tows), these were analyzed with two-tailed, paired $t$-tests $(P \leq 0.05)$. In experiment 1, catches of the three key fish species (yellowfin bream, Acantopagrus australis; silver biddy, Gerres subfasciatus; and southern herring, Herklotsichthys castelnaui) were combined to provide a larger data set. To examine the relative effectiveness of the various BRDs, the differences in catches (between each treatment BRD and the 600 Nordmøre-grid) for those variables that were non-zero in all tows were $\ln \left(\mathrm{x}+10^{2}\right.$ or $\left.10^{4}\right)$ transformed, tested for heteroscedasticity using Cochran's test and analyzed using appropriate analyses of variance (ANOVA) (BRDs and days were treated as fixed and random factors, respectively). Significant differences detected in these analyses were investigated by Student-Newman-Keuls (SNK) multiple comparisons of means. Where analyses provided similar results for weights and numbers of variables, only data
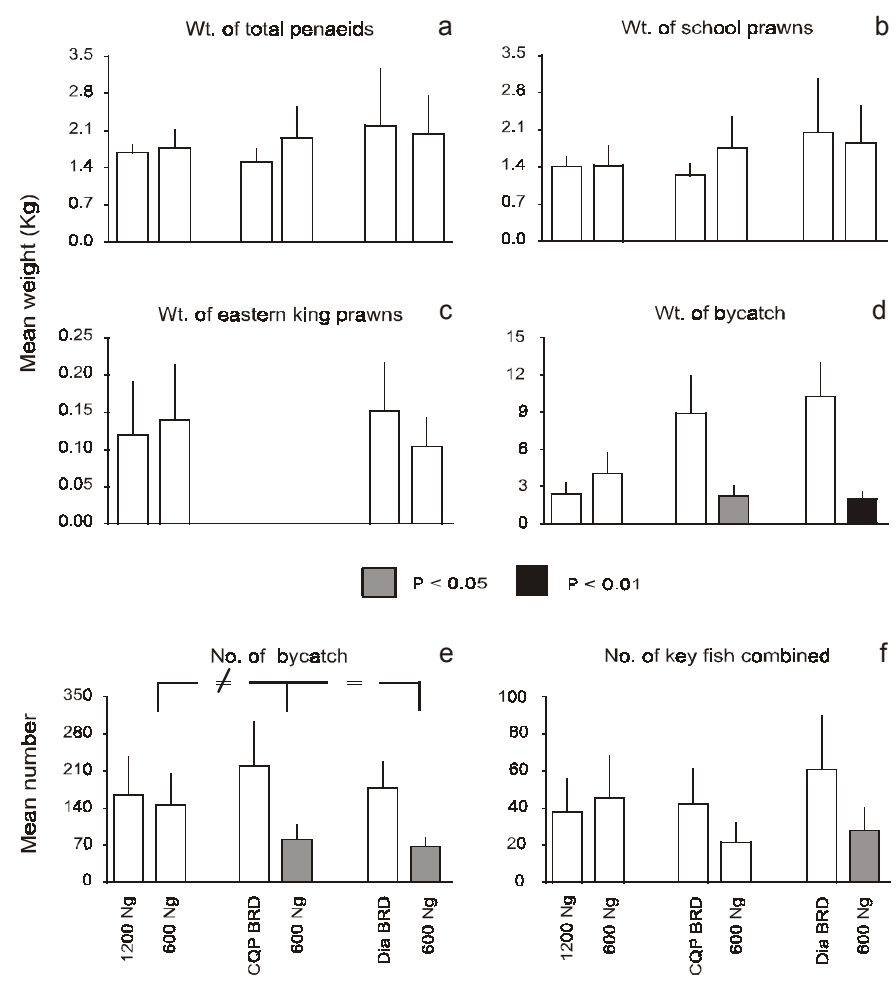

eficacia relativa de los diversos BRDs, las diferencias entre las capturas (entre cada BRD experimental y la rejilla Nordmøre 600) para las variables diferentes de cero en todos los arrastres se transformaron a $\ln \left(\mathrm{x}+10^{2}\right.$ ó $\left.10^{4}\right)$, se examinó su heterocedasticidad usando la prueba de Cochran, y se les aplicó los análisis de varianza (ANOVA) apropiados (considerando a los BRDs y los días como factores fijo y aleatorio, respectivamente). Las diferencias significativas detectadas en estos análisis se analizaron con la pueba de Student-Newman-Keuls (SNK) para la comparación múltiple de medias. Cuando los análisis arrojaron resultados similares para pesos y números de variables, sólo se incluyeron los datos referentes a los pesos para conservar espacio. Se combinaron las frecuencias de talla de langostinos y peces de todos los arrastres y cuando hubieron suficientes datos ( $>40$ individuos en cada copo), se compararon con las pruebas de Kolmogorov-Smirnov para dos muestras $(P \leq 0.05)$.

\section{Resultados}

\section{Experimento 1: rejilla Nordmøre convencional vs rejilla Nordmøre modificada y dos BRDs de tipo conductual}

No se detectaron diferencias significativas en las capturas de peneidos entre la rejilla Nordmøre 600 convencional y los tres BRDs experimentales (pruebas $t$ pareadas, $P>0.05$, $n=10$ ) (fig. $4 \mathrm{a}-\mathrm{c}$ ). En comparación con la rejilla convencional, los BRDs de diamante y de paño de calidad Clarence retuvieron significativamente mayores pesos (pruebas $t$ pareadas, $P<0.05$ y 0.01 , respectivamente, $n=10)$ y número de individuos (pruebas $t$ pareadas, $P<0.05, n=10$ ) de fauna acompañante (capturas medias hasta cinco veces mayores) (fig. 4 d, e). El BRD de diamante también retuvo un número significativamente mayor de los peces clave combinados (A. australis, G. subfasciatus y $H$. castelnaui) que la rejilla Nordmøre 600 (hasta tres veces más, prueba $t$ pareada, $P<0.05, n=10)$, y aunque no de manera significativa, el BRD

Figure 4. Mean catches per 20-min tow $(+S E)$ between the various treatment BRDs and the 600 Nordmøre-grid $(\mathrm{Ng})$ for the weights of (a) total penaeids, (b) school prawns, (c) eastern king prawns, and (d) bycatch, and the numbers of (e) bycatch and (f) key species (yellowfin bream, Acantopagrus australis; silver biddy, Gerres subfaciatus; and southern herring, Herklotsichthys castelnaui) combined. CQP BRD: Clarence quality panel bycatch reduction device; Dia BRD: diamond bycatch reduction device; shading indicates significant differences with adjacent (i.e., paired) histogram; = and $\neq$ indicate direction of differences in SNK tests.

Figura 4. Capturas medias por cada arrastre de $20 \mathrm{~min}(+\mathrm{EE})$ de los varios BRDs experimentales y la rejilla Nordmøre (Ng) 600 para los pesos de (a) peneidos totales, (b) Metapenaeus macleayi, (c) Penaeus plebejus y (d) fauna acompañante, y los números de (e) fauna acompañante y (f) especies clave combinadas (Acantopagrus australis, Gerres subfaciatus y Herklotsichthys castelnaui). CQP BRD: dispositivo para la reducción de la fauna acompañante (BRD) de paño de calidad Clarence; Dia BRD: BRD de diamante; el sombreado indica diferencias significativas con el histograma (i.e., pareado) adyacente; $=\mathrm{y} \neq$ indican la dirección de las diferencias en las pruebas de SNK. 
Table 1. Experiment 1: $F$ ratios from two-factor analyses of variance to determine effects on catches due to fishing wih three different $B R D s$ on five different days. All data were $\ln \left(x+10^{2}\right.$ or $\left.10^{4}\right)$ transformed. ${ }^{*}$ Significant $(P<0.01)$; ${ }^{*}$ significant $(P<0.05)$. YB, yellowfin bream; SB, silver biddy; SH, southern herring; "pld" indicates that the interaction was non-significant at $P<0.25$ and the sums of squares pooled with the residual. Tabla 1. Experimento 1: razones $\mathrm{F}$ de los análisis de varianza de dos factores para determinar los efectos sobre las capturas de pesca utilizando tres diferentes BRDs en cinco días diferentes. Todos los datos se transformaron a $\ln \left(\mathrm{x}+10^{2}\right.$ ó $\left.10^{4}\right)$. ${ }^{* *}$ Significativo $(P<0.01)$; * significativo $(P<0.05)$. YB, Acantopagrus australis; SB, Gerres subfasciatus; SH, Herklotsichthys castelnaui; "pld" indica una interacción no significativa a $P<0.25$ y las sumas de cuadrados combinados con el residual.

\begin{tabular}{|c|c|c|c|c|c|c|c|c|}
\hline \multirow{2}{*}{ Treatment } & \multirow{2}{*}{$\mathrm{df}$} & \multicolumn{2}{|c|}{ Total penaeids } & \multicolumn{2}{|c|}{ School prawns } & \multicolumn{2}{|c|}{ Bycatch } & \multirow{2}{*}{$\begin{array}{c}\text { No. of } \\
\text { YB/SB/SH }\end{array}$} \\
\hline & & No. & Wt. & No. & Wt. & No. & Wt. & \\
\hline Days & 4 & 1.88 & 1.47 & 1.62 & 1.71 & $9.37 * *$ & $3.49 *$ & 12.20 \\
\hline BRDs & 2 & 1.13 & 1.08 & 1.31 & 0.94 & $4.06^{*}$ & 3.68 & 2.04 \\
\hline Interaction & 8 & $0.23^{\text {pld }}$ & $0.32^{\text {pld }}$ & $0.27^{\text {pld }}$ & $0.37^{\text {pld }}$ & $1.46^{\mathrm{pld}}$ & $3.72 *$ & $1.28^{\mathrm{pld}}$ \\
\hline Residual & 15 & & & & & & & \\
\hline
\end{tabular}

concerning weights were included to conserve space. Sizefrequencies of prawns and fish were combined across all tows and where there were sufficient data ( $>40$ individuals in each codend), they were compared with two-sample KolmogorovSmirnov tests $(P \leq 0.05)$.

\section{Results}

\section{Experiment 1: the conventional Nordmøre-grid vs a modified Nordmøre-grid and two behavioral-type BRDs}

No significant differences were detected in the catches of penaeids between the 600 Nordmøre-grid and the three treatment BRDs (paired $t$-tests, $P>0.05, n=10$ ) (fig. $4 \mathrm{a}-\mathrm{c}$ ). Compared to the 600 Nordmøre-grid, the diamond and Clarence quality panel BRDs retained significantly greater weights (paired $t$-tests, $P<0.05$ and 0.01 , respectively, $n=10$ ) and numbers (paired $t$-tests, $P<0.05, n=10$ ) of bycatch (mean catches up to five times greater) (fig. $4 \mathrm{~d}$, e). The diamond BRD also retained significantly more key fish combined (bream, southern herring and silver biddy) than did the 600 Nordmøregrid (up to three times more, paired $t$-test, $P<0.05, n=10$ ) and although not significant, the Clarence quality panel BRD caught relatively similar numbers of these fish (paired $t$-test, $P>0.05, n=10$ ) (fig. 4f). ANOVA of the differences in catches between the treatment BRDs and the 600 Nordmøregrid detected a significant interaction for the weight of bycatch and differences in the numbers of bycatch for the main effects of BRDs and days. Appropriate SNK tests of these means revealed no definitive order for the interaction, but showed that the Clarence quality panel and diamond BRDs retained similar numbers of bycatch, which were significantly greater than the 1200 Nordmøre-grid $(P<0.05)$ (fig. 4e; table 1).

Two sample Kolmogorov-Smirnov tests failed to detect significant differences in the relative size-frequency distributions of school prawns retained in the codends containing the treatment BRDs and the 600 Nordmøre-grid $(P>0.05)$. The size-frequency compositions of bream retained in the Clarence quality panel and diamond BRDs and southern herring retained de paño de calidad Clarence capturó números relativamente similares de estos peces (prueba $t$ pareada, $P>0.05, n=10$ ) (fig. 4f). Los ANOVA de las diferencias entre las capturas de los BRDs experimentales y aquellas obtenidas usando la rejilla convencional detectaron una interacción significativa del peso de la fauna acompañante y diferencias en los números de individuos de ésta para los efectos principales de BRDs y días. Las pruebas de SNK apropiadas para estas medias no mostraron un orden definitivo en la interacción, pero indicaron que los BRDs de paño de calidad Clarence y diamante retuvieron números de organismos similares de fauna acompañante, que fueron significativamente mayores que los de la rejilla Nordmøre $1200(P<0.05)$ (fig. 4e; tabla 1$)$.

Las pruebas de Kolmogorov-Smirnov para dos muestras no detectaron diferencias significativas en las distribuciones relativas de la frecuencia de talla de los individuos de M. macleayi retenidos en los copos que contenían los BRDs experimentales y la rejilla Nordmøre $600(P>0.05)$. Las composiciones de frecuencia de talla de individuos de $A$. australis retenidos en los BRDs de paño de calidad Clarence y diamante, y de $H$. castelnaui retenidos en la rejilla Nordmøre 1200 y el BRD de diamante fueron significativamente diferentes a los retenidos por la rejilla convencional $(P<0.05)$ (fig. 5a, b). En todos los casos, ambos BRDs conductuales retuvieron proporcionalmente más peces de mayor tamaño. En contraste, la rejilla Nordmøre 1200 retuvo significativamente menos individuos grandes de $H$. castelnaui que la rejilla convencional (fig. 5b).

\section{Experimento 2: rejilla Nordmøre convencional vs. tres rejillas Nordmøre modificadas}

En comparación con la rejilla Nordmøre 600, la rejilla Nordmøre 900 curva retuvo significativamente menos peso de M. macleayi (medias reducidas por $15.7 \%$; prueba $t$ pareada, $P<0.05, n=14$ ), número y peso de la fauna acompañante (por $33.4 \%$ y $25 \%$, respectivamente; prueba $t$ pareada, $P<0.05$, $n=14$ ), y número de G. subfasciatus (por $42.5 \%$; prueba $t$ pareada, $P<0.01, n=14$ ) (fig. $6 \mathrm{a}-\mathrm{d}, \mathrm{h}$ ). Las pruebas $t$ pareadas 


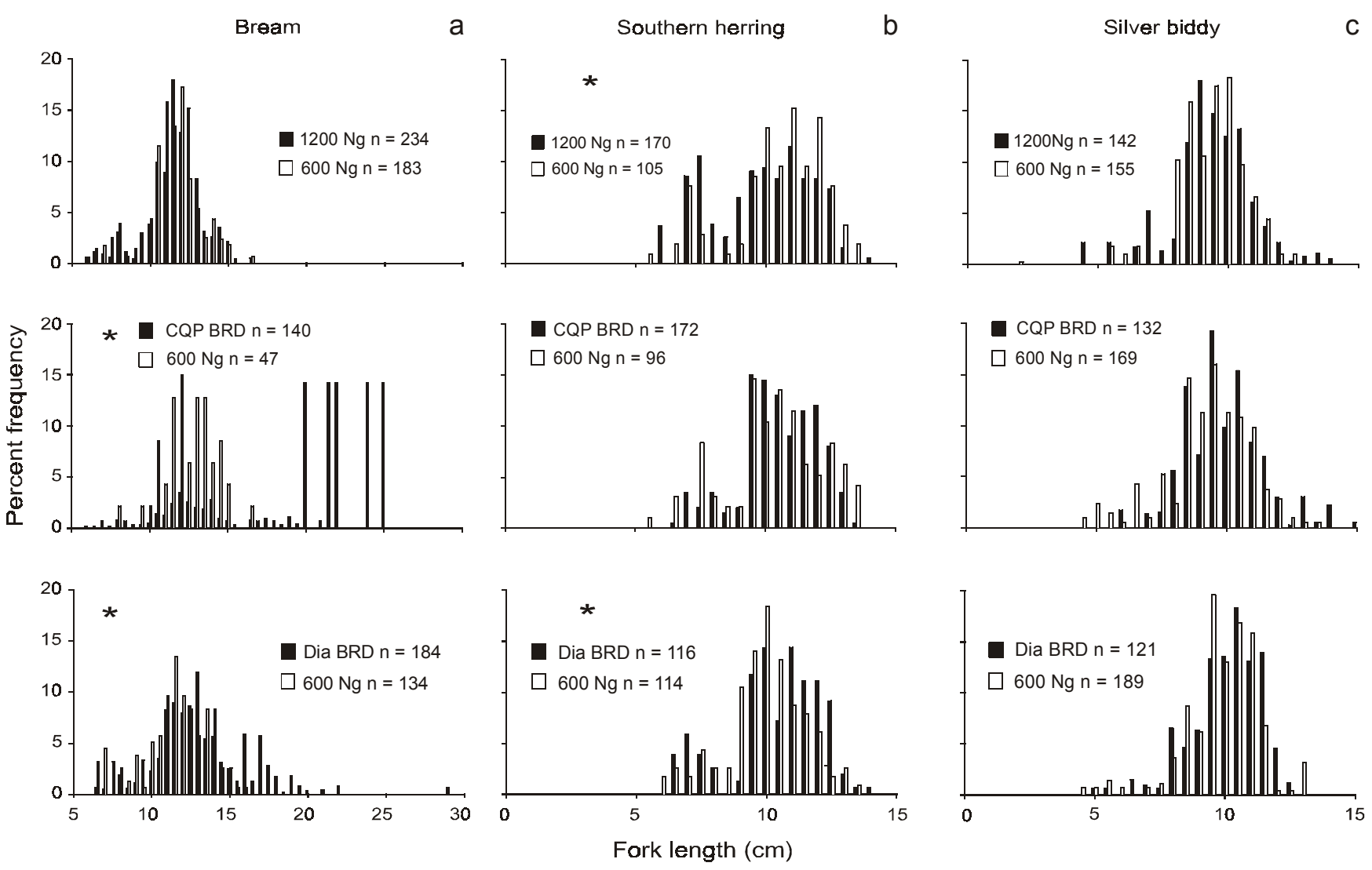

Figure 5. Size-frequency distributions of (a) yellowfin bream Acantopagrus australis, (b) southern herring Herklotsichthys castelnaui, and (c) silver biddy Gerres subfaciatus from the various treatment BRDs and 600 Nordmøre-grid (Ng) used in experiment 1. CQP BRD: Clarence quality panel bycatch reduction device; Dia BRD: diamond bycatch reduction device; * significant $(P>0.05)$ difference detected in Kolmogorov Smirnov test.

Figura 5. Distribución de la frecuencia de talla de (a) Acantopagrus australis, (b) Herklotsichthys castelnaui y (c) Gerres subfaciatus de los BRDs experimentales y la rejilla Nordmøre $(\mathrm{Ng}) 600$ que se usaron en el experimento 1. CQP BRD: BRD de paño de calidad Clarence; Dia BRD: BRD de diamante; * diferencia significativa $(P>0.05)$ detectada en la prueba Kolmogorov Smirnov.

in the 1200 Nordmøre-grid and diamond BRD were significantly different to those retained in the 600 Nordmøre-grid $(P<0.05)$ (fig. 5a, b). In all cases, both behavioral-type BRDs retained proportionally more larger-sized fish. In contrast, the 1200 Nordmøre-grid retained significantly fewer large southern herring than did the 600 Nordmøre-grid (fig. 5b).

\section{Experiment 2: the conventional Nordmøre-grid vs three modified Nordmøre-grids}

Compared to the 600 Nordmøre-grid, the curved 900 Nordmøre-grid retained a significantly lower weight of school prawns (means reduced by $15.7 \%$; paired $t$-test, $P<0.05$, $n=14$ ), number and weight of bycatch (by $33.4 \%$ and $25 \%$, respectively; paired $t$-test, $P<0.05, n=14)$ and number of silver biddy (by 42.5\%; paired $t$-test, $P<0.01, n=14$ ) (fig. 6a-d, h). Paired $t$-tests failed to detect any other significant differences between the 600 and various treatment Nordmøre-grids $(P>0.05)$ (fig. 6). ANOVA of the differences between the 600 and treatment Nordmøre-grids detected significant differences in the numbers and weights of school prawns and the numbers of bycatch for the main effect of no detectaron otras diferencias significativas entre la rejilla convencional y las experimentales $(P>0.05)$ (fig. 6). Los ANOVA de las diferencias entre la rejilla convencional y las experimentales detectaron diferencias significativas en los números y pesos de $M$. macleayi y el número de organismos de cada especie de la fauna acompañante para el efecto principal de los BRDs (tabla 2). Las pruebas de SNK de estas medias mostraron que la rejilla Nordmøre 600 curva retuvo significativamente más individuos de $M$. macleayi y fauna incidental que la rejilla 900 curva, pero cantidades similares a la rejilla 900 $(P<0.05)$ (fig. 6a-c). No se detectaron diferencias significativas entre la rejilla Nordmøre 900 y la 900 curva para las capturas de M. macleayi, mientras que la rejilla 900 curva retuvo menos fauna acompañante (fig. 6c).

Las pruebas de Kolmogorov-Smirnov para dos muestras no detectaron diferencias significativas en las distribuciones de frecuencia de talla de peces entre la rejilla Nordmøre 600 y las experimentales $(P>0.05)$. Se encontraron diferencias para $M$. macleayi, con las rejillas Nordmøre 900 curva y 600 curva reteniendo significativamente menos individios de talla grande $(P<0.05)$ (fig. 7). 


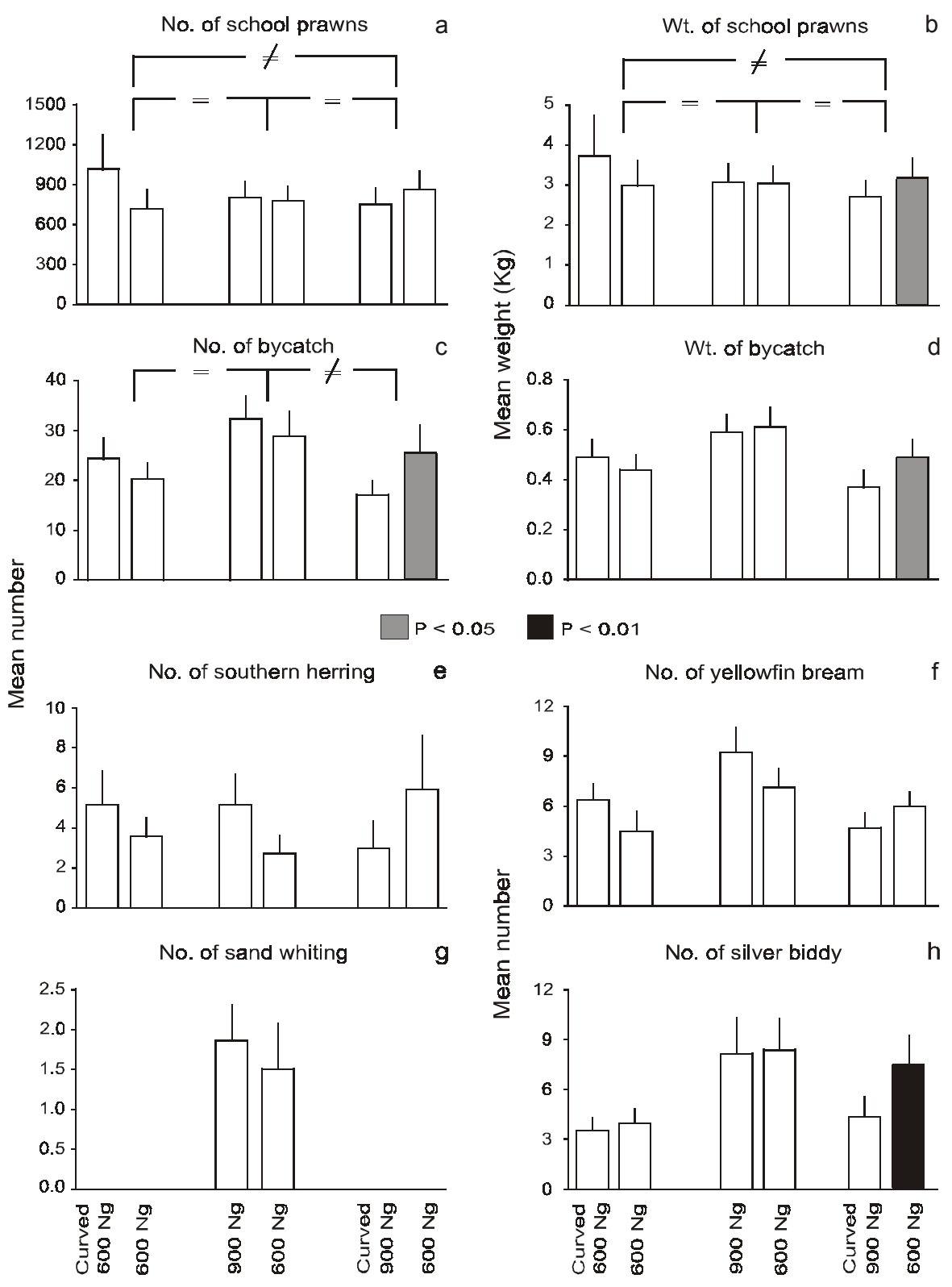

Figure 6. Mean catches per 20-min tow (+SE) between the various treatment Nordmøre-grids ( $\mathrm{Ng})$ and the 600 Nordmøre-grid for the (a) numbers and (b) weights of school prawns, (c) numbers and (d) weights of bycatch, and the numbers of (e) southern herring, (f) yellowfin bream, (g) sand whiting, and (h) silver biddy. Shading indicates significant differences with adjacent (i.e. paired) histogram; = and $\neq$ indicate direction of differences in SNK tests. Figura 6. Capturas medias por cada arrastre de $20 \mathrm{~min}(+\mathrm{EE})$ entre las rejillas Nordmøre (Ng) experimentales y la rejilla Nordmøre 600 para los (a) números y (b) pesos de Metapenaeus macleayi, (c) números y (d) pesos de la fauna acompañante, y los números de (e) Herklotsichthys castelnaui, (f) Acantopagrus australis, (g) Sillago ciliata y (h) Gerres subfaciatus. El sombreado indica diferencias significativas con el histograma (i.e., pareado) adyacente; $=\mathrm{y} \neq$ indican la dirección de las diferencias de las pruebas de SNK.

BRDs (table 2). SNK tests of these means showed that the curved 600 Nordmøre-grid retained significantly more school prawns and bycatch than the curved 900 Nordmøre-grid, but similar quantities as the 900 Nordmøre-grid $(P<0.05$; fig. $6 \mathrm{a}-\mathrm{c}$ ). No significant differences were detected between the 900 and the curved 900 Nordmøre-grids for the catches of school prawns, while the curved 900 Nordmøre-grid retained less numbers of bycatch (fig. 6c).

\section{Discusión}

Los resultados presentados en este trabajo sustentan estudios previos que han mostrado que los BRDs de tipo mecánico son generalmente más efectivos para separar organismos que los BRDs que funcionan según las diferencias en el comportamiento y/o fisiología de las especies (e.g., Broadhurst et al., 1996; Madsen y Hansen, 2001). Asimismo, al comprobrar que 
Broadhurst et al.: Effects of Nordmøre-grid angles, profiles and other BRDs

Table 2. Experiment 2: $F$ ratios from two-factor analyses of variance to determine effects on catches due to fishing with three different BRDs on seven different days. All data were $\ln \left(x+10^{2}\right.$ or $\left.10^{4}\right)$ transformed. ${ }^{*}$ Significant $(P<0.01)$; * Significant $(P<0.05)$; "pld" indicates that the interaction was non-significant at $P<0.25$ and the sums of squares pooled with the residual.

Tabla 2. Experimento 2: razones $\mathrm{F}$ de los análisis de varianza de dos factores para determinar los efectos sobre las capturas de pesca utilizando tres diferentes BRDs en siete días diferentes. Todos los datos se transformaron a $\ln \left(x+10^{2}\right.$ ó $\left.10^{4}\right)$. ${ }^{* *}$ Significativo $(P<0.01)$; * significativo $(P<0.05)$; "pld" indica una interacción no significativa a $P<0.25$ y las sumas de cuadrados combinados con el residual.

\begin{tabular}{|c|c|c|c|c|c|c|c|}
\hline \multirow[b]{2}{*}{ Treatment } & \multirow[b]{2}{*}{$\mathrm{df}$} & \multicolumn{2}{|c|}{ School prawns } & \multicolumn{2}{|c|}{ Bycatch } & \multirow{2}{*}{$\begin{array}{c}\text { No. of } \\
\text { yellowfin bream }\end{array}$} & \multirow{2}{*}{$\begin{array}{c}\text { No. of } \\
\text { silver biddy }\end{array}$} \\
\hline & & No. & Wt. & No. & Wt. & & \\
\hline Days & 6 & 0.36 & 0.41 & 0.68 & 0.55 & 0.72 & 0.50 \\
\hline BRDs & 2 & $3.54^{*}$ & $4.35^{*}$ & $7.42 * *$ & 1.84 & 3.15 & 1.58 \\
\hline Interaction & 12 & $0.96^{\text {pld }}$ & $1.23^{\text {pld }}$ & $0.82^{\text {pld }}$ & 1.96 & $0.82^{\text {pld }}$ & $0.52^{\text {pld }}$ \\
\hline Residual & 21 & & & & & & \\
\hline
\end{tabular}

Two sample Kolmogorov-Smirnov tests failed to detect any significant differences in size-frequency distributions of fish between the treatment Nordmøre-grids and the 600 Nordmøregrid $(P>0.05)$. Differences were detected for school prawns, with the curved 900 and curved 600 Nordmøre-grids retaining significantly fewer larger-sized individuals $(P<0.05)$ (fig. 7).

\section{Discussion}

The results presented here support previous studies which have shown that mechanical-type BRDs generally are more effective at separating organisms than BRDs that exploit differences in species' behavior and/or physiology (e.g., Broadhurst et al., 1996; Madsen and Hansen, 2001). Further, by demonstrating that the majority of modifications to the size, installation angle and profile of the Nordmøre-grid did not negatively affect its performance, we have illustrated the robustness of this mechanical-type BRD for consistently excluding unwanted organisms, while maintaining catches of the targeted penaeids.

Compared to the behavioral-type BRDs examined in experiment 1 , the commercially used 600 Nordmøre-grid retained up to $80 \%$ less total bycatch and $67 \%$ fewer individuals of the key fish combined (i.e., yellowfin bream, silver biddy and southern herring) (fig. 4d-f). These sorts of differences are similar to those observed during several previous experiments where the Nordmøre-grid was tested against codends with no BRD (e.g., Broadhurst et al., 1996; Broadhurst and Kennelly, 1996a). As an example, Broadhurst and Kennelly (1996a) showed that the 600 Nordmøre-grid significantly reduced the weight of total bycatch and number of bream by $76 \%$ and $67 \%$, respectively. Such comparable differences suggest that few organisms (if any) escaped from the diamond and Clarence quality panel BRDs examined during experiment 1. This conclusion is supported by Broadhurst et al. (1996), who showed that few individuals escaped through large-mesh panels located at similar positions in the codends of Clarence River trawlers, but conflicts with the demonstrated la mayoría de las modificaciones al tamaño, ángulo de instalación y perfil de las rejillas Nordmøre no afectaron negativamente su funcionamiento, se ha demostrado la eficacia de este BRD mecánico para excluir de manera consistente los organismos no deseados y retener los peneidos deseados.

En comparación con los BRDs de tipo conductual del experimento 1, la rejilla Nordmøre 600 convencional retuvo hasta $80 \%$ menos fauna acompañante total y $67 \%$ menos individuos de los peces clave combinados (i.e., A australis, $G$. subfasciatus y $H$. castelnaui) (fig. 4d-f). Estas diferencias son similares a las observadas durante varios experimentos previos en los cuales se comparó el funcionamiento de la rejilla Nordmøre con el de copos sin BRDs (e.g., Broadhurst et al., 1996; Broadhurst y Kennelly, 1996a). Como ejemplo, Broadhurst y Kennelly (1996a) mostraron que la rejilla Nordmøre 600 redujo significativamente el peso de la fauna acompañante total y el número de $A$. australis en $76 \%$ y $67 \%$, respectivamente. Estas diferencias comparables sugieren que pocos organismos (si es que alguno) escapan de los BRDs de diamante y paño de calidad Clarence probados en el experimento 1. Esta conclusión es respaldada por Broadhurst et al. (1996), quienes mostraron que pocos individuos escapan por paños de malla grande localizados en posiciones similares en los copos de barcos de arrastre del Río Clarence, pero contrasta con la eficacia mostrada por BRDs similares en otras pesquerías locales y extranjeras (e.g., Broadhurst y Kennelly, 1996b; Rogers et al., 1997; Broadhurst et al., 2002a, 2002b).

El pobre desempeño relativo de los BRDs de diamante y paño de calidad Clarence puede atribuirse a factores específicos de las especies y operacionales asociados con la pesquería del Río Clarence. Broadhurst et al. (1996) sugirieron que algunos peces, como A. australis, pueden no presentar una respuesta activa de escape vertical en los copos, impidiendo efectivamente su salida por las aperturas en ambos BRDs. Otra hipótesis incluye varias características operacionales de los barcos de arrastre del Río Clarence, incluyendo tiempos de arrastre cortos y cobrado rápido de las redes. En otros trabajos se ha mencionado que algunos peces pequeños se acumulan y se mantienen al frente de los demás organismos capturados 
School prawns
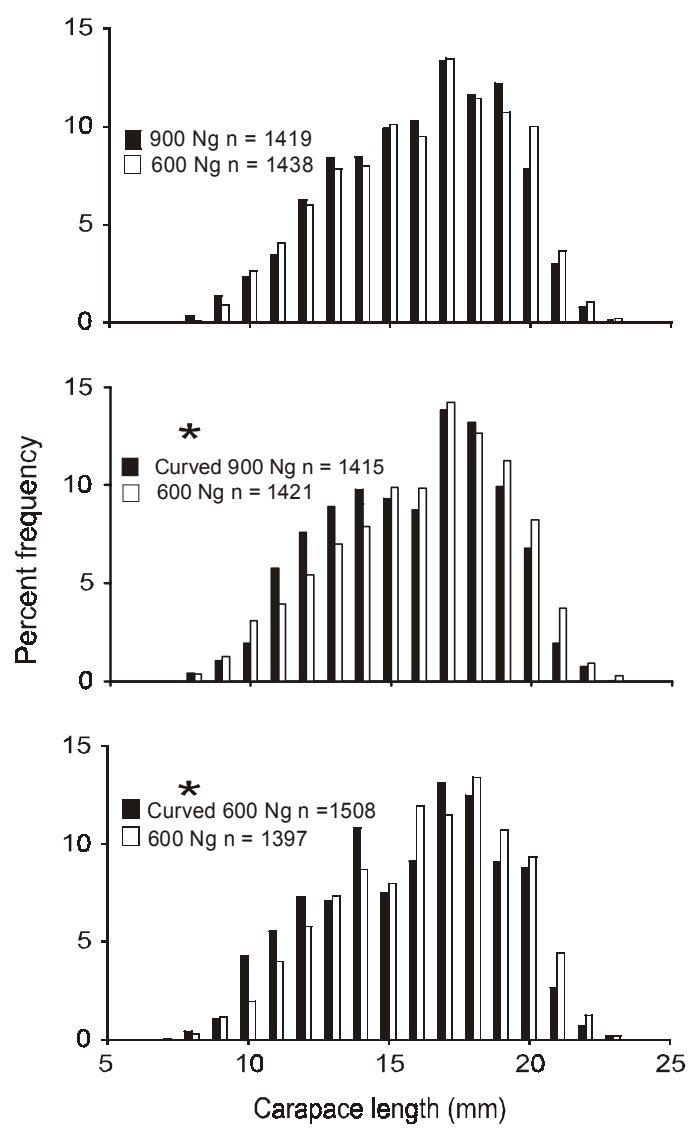

Figure 7. Size-frequency distributions of school prawns from the various treatment Nordmøre-grids $(\mathrm{Ng})$ and 600 Nordmøre-grid used in experiment 2. ; * significant $(P>0.05)$ difference detected in Kolmogorov Smirnov test. Figura 7. Distribución de la frecuencia de talla de Metapenaeus macleayi de las rejillas Nordmøre $(\mathrm{Ng})$ experimentales y la rejilla Nordmøre 600 que se usaron en el experimento 2. ${ }^{*}$ diferencia significativa $(P>0.05)$ detectada en la prueba Kolmogorov Smirnov

utility of similar BRDs in other local and overseas fisheries (e.g., Broadhurst and Kennelly, 1996b; Rogers et al., 1997; Broadhurst et al., 2002a, 2002b).

The poor relative performance of the diamond and Clarence quality panel BRDs may be attributed to species- and operational-specific factors associated with the Clarence River fishery. Specifically, Broadhurst et al. (1996) suggested that some fish, such as yellowfin bream, may not display an active escape response upwards in codends, effectively precluding their escape through the openings in either BRD. A related hypothesis involves several operational characteristics of Clarence River trawlers that include a short tow duration and fast retrieval of trawls. Observations made in other studies have revealed that some small fish accumulate and maintain position in front of the catch during towing and then, owing to changes in tactile and visual stimuli, collectively escape through the openings of behavioral-type BRDs when the vessel is stopped and the trawl is slowly winched to the surface (e.g., Watson, 1989; Rogers et al., 1997). Clarence River trawlers durante el arrastre y luego, debido a cambios en los estímulos táctiles y visuales, escapan colectivamente por las aperturas de los BRDs conductuales al detenerse el barco y cobrar la red (e.g., Watson, 1989; Rogers et al., 1997). Los arrastreros del Río Clarence cobran sus redes con rapidez de agua somera (principalmente $<10 \mathrm{~m}$ ) y sin dar marcha atrás, lo cual limita la oportunidad de los peces para escapar por las aperturas en el copo.

Estos tipos de factores operacionales no afectaron el desempeño de la rejilla Nordmøre que consistentemente redujo la captura de fauna acompañante y mantuvo la captura de peneidos con la mayoría de las configuraciones y ángulos de instalación. Estas observaciones son similares a las registradas por Larsen (1996) en un estudio que comparó una rejilla Nordmøre convencional instalada a aproximadamente $48^{\circ}$ con una rejilla más larga instalada a aproximadamente $23^{\circ}$ en artes camaroneros del Mar del Norte. En este estudio previo, la rejilla más larga mantuvo las capturas de la especie objetivo pero redujo ligeramente las de fauna acompañante, lo cual se atribuyó a la mayor área superficial (ofreciendo más oportunidades para que los camarones pasen por las barras) y al flujo de agua más rápido por la rejilla con un menor ángulo (facilitando el movimiento de los peces por la apertura de escape). Las rejillas Nordmøre 900 y 1200 probadas en este estudio no excluyeron similarmente más fauna incidental que la rejilla convencional, pero esto puede explicarse por la configuración del paño de guía. A diferencia de las rejillas Nordmøre utilizadas en barcos camaroneros del Mar del Norte, que tienen un conducto de guía que acaba $1 \mathrm{~m}$ antes de la base de la rejilla, los diseños usados en el Río Clarence tienen un paño que se extiende hasta la superficie de la rejilla y eslabones de cadena que le dan peso (fig. 3). Esto significa que todos los organismos salen del paño de guía en la superficie de la rejilla y son inmediatamente clasificados, independientemente del ángulo de la rejilla y de cualquier efecto secundario del flujo de agua. Recorrer la apertura posterior de la apertura de guía hacia adelante y/o quitar los eslabones de cadena probablemente impediría el paso de peces pequeños por las barras y dejaría que más de ellos escaparan, pero implicaría también la pérdida de algunos peneidos (Isaksen et al., 1992).

$\mathrm{Al}$ igual que los cambios en el ángulo y el área superficial de las rejillas discutidos anteriormente, la modificación del perfil para incluir una sección superior curva para prevenir la acumulación de algas o basura no influyó en las capturas retenidas con la rejilla Nordmøre 600. Sin embargo, esta misma modificación a la rejilla Nordmøre 900 sí representó una reducción significativa y similar en los pesos de fauna acompañante y de $M$. macleayi (en $25 \%$ y $15 \%$, respectivamente, en comparación con la rejilla Nordmøre 600; fig. 6). La mayoría de los peces que se escaparon de la rejilla lo hicieron sin importar su tamaño, ya que la prueba de KolmogorovSmirnov no detectó diferencias entre BRDs. En contraste, aparentemente más individuos grandes de M. macleayi se escaparon de la rejilla Nordmøre 900 curva (fig. 7). En ausencia de video submarino u observaciones directas, es difícil explicar 
Broadhurst et al.: Effects of Nordmøre-grid angles, profiles and other BRDs

retrieve their nets very quickly, from shallow water (mostly $<10 \mathrm{~m}$ ) and with no delay in haul back. This would limit the opportunity for any swimming fish to escape through openings in the codend.

These sorts of operational factors did not affect the performance of the Nordmøre-grid that consistently reduced bycatch and maintained catches of penaeids across most configurations and all angles of installation. These observations are comparable to those made by Larsen (1996) in a related study comparing a conventional Nordmøre-grid installed at approximately $48^{\circ}$ with a longer grid installed at approximately $23^{\circ}$ in North Sea shrimp trawls. In this earlier work, the longer grid similarly maintained catches of the targeted shrimp, but slightly reduced the bycatch. This was attributed to the larger area (allowing more opportunities for shrimp to pass between the bars) and a faster flow of water along the low-angled grid (facilitating the movement of fish through the escape exit). The 900 and 1200 Nordmøre-grids examined here did not similarly exclude more bycatch than the conventional grid, but this may be explained by the configuration of the guiding panel. Unlike the Nordmøre-grids used in North Sea shrimp trawls that have a guiding funnel which terminates up to $1 \mathrm{~m}$ anterior to the base of the grid, the designs used in the Clarence River have a panel that extends to the surface of the grid and is weighted with chain links (fig. 3). This means that all organisms exit the guiding panel against the surface of the grid and are sorted immediately, irrespective of the grid angle and any ancillary effects on water flow. Moving the posterior opening of the guiding opening forwards and/or removing the chain links would probably prevent small fish being forced through the bars and allow more to escape, but this may correspond to some loss of penaeids (Isaksen et al., 1992).

Like the changes to the angle and surface area of grids discussed above, altering the profile to include a curved upper section designed to prevent weed and debris from accumulating had no effect on catches retained in 600 Nordmøre-grid. However, the same modification to the 900 Nordmøre-grid resulted in significant and similar reductions in the weights of bycatch and school prawns (by $25 \%$ and $15 \%$, respectively compared to the 600 Nordmøre-grid; fig. 6). Most fish escaping from this grid did so across all sizes, since Kolmogorov-Smirnov tests failed to detect any differences between BRDs. In contrast, more larger-sized school prawns appear to have escaped from the curved 900 Nordmøre-grid (fig. 7). In the absence of underwater video or direct observations, it is difficult to postulate reasons for these reductions in catches. One possible explanation is that this grid was not sufficiently buoyed (i.e., $6 \times 100 \mathrm{~mm}$ floats) to compensate for the extra aluminum required in its construction and it may have twisted during fishing, randomly releasing some of the catch.

Despite the above, neither of the curved Nordmøregrids had weed or objects fouled along their top edges (unlike the conventional design), and so commercial fishers have begun trialing various similar, low-angled and modified-profile grids. Such ongoing development and refinement to the estas reducciones en la captura. Una posible explicación es que la flotación de la rejilla (i.e., boyas de $6 \times 100 \mathrm{~mm}$ ) no fue suficiente para compensar el aluminio adicional que se utilizó en su construcción y que la rejilla se haya torcido durante la pesca, liberando al azar parte de la captura.

A pesar de lo anterior, ninguna de las rejillas Nordmøre curvas presentaron algas o basura a lo largo de sus bordes superiores (a diferencia del diseño convencional), por lo que algunos pescadores ya comienzan a probar varias rejillas similares de ángulo bajo y perfil modificado. Este desarrollo y perfeccionamiento progresivo de la rejilla Nordmøre eventualmente atenderá las necesidades de los pescadores del Río Clarence. Asimismo, aunque cualquier modificación sutil puede ser específica para esta pesquería en particular, los conceptos básicos analizados aquí deberían investigarse en otras pesquerías que usan BRDs de tipo mecánico similares.

\section{Agradecimientos}

Se agradece a Jennifer Rowling su asistencia técnica; a Roger Larsen y a Don y Barry Johnson sus comentarios; y a Steve Kennelly, Charles Gray y Paul O’Conner la revisión del manuscrito.

Traducido al español por Christine Harris.

Nordmøre-grid should eventually address the requirements of the Clarence River fishers. It is also likely that, while any subtle modifications may be specific to this particular fishery, the basic concepts examined here may warrant investigation in other fisheries that use similar mechanical-type BRDs.

\section{Acknowledgements}

Thanks are extended to Jennifer Rowling for technical assistance; Roger Larsen and Don and Barry Johnson for their advice and expertise; and Steve Kennelly, Charles Gray and Paul O'Conner for critically reviewing the manuscript.

\section{References}

Alverson, D.L., Freeberg, M.H., Murawski, S.A. and Pope, J.G. (1994). A global assessment of fisheries bycatch and discards. FAO Fish. Tech. Pap. No. 339, 233 pp.

Andrew, N.L. and Pepperell, J.G. (1992). The by-catch of shrimp trawl fisheries. Oceanogr. Mar. Biol. Ann. Rev., 30: 527-565.

Anon (1978). FAO Catalogue of Fishing Gear Designs. Fishing News Books, Surrey, England, 160 pp.

Broadhurst, M.K. (2000). Modifications to reduce bycatch in prawn trawls: A review and framework for development. Rev. Fish Biol. Fish., 10: 27-60.

Broadhurst, M.K. and Kennelly, S.J. (1996a). Rigid and flexible separator-panels in trawls that reduce the by-catch of small fish in the Clarence River prawn-trawl fishery, Australia. Mar. Freshwater Res., 47: 991-998.

Broadhurst, M.K. and Kennelly, S.J. (1996b). Effects of the circumference of codends and a new design of square-mesh panel 
in reducing unwanted by-catch in the New South Wales oceanic prawn-trawl fishery, Australia. Fish. Res., 27: 203-214.

Broadhurst, M.K., Kennelly, S.J. and Isaksen, B. (1996). Assessments of modified codends that reduce the by-catch of fish in two estuarine prawn-trawl fisheries in New South Wales, Australia. Fish. Res., 27: 89-111.

Broadhurst, M.K., Kennelly, S.J. and O'Doherty, G. (1997). Specifications for the construction and installation of two bycatch reducing devices (BRDs) used in New South Wales prawntrawl fisheries. Mar. Freshwater Res., 48: 485-489.

Broadhurst, M.K., Kennelly, S.J. and Cray, C.A. (2002a). Optimal positioning and design of behavioural-type by-catch reduction devices involving square-mesh panels in penaeid prawn-trawl codends. Mar. Freshwater Res., 53: 813-823.

Broadhurst, M.K., Kangas, M.I., Daminao, C., Bickford, S.A. and Kennelly, S.J. (2002b). Using composite square-mesh panels and the Nordmøre-grid to reduce bycatch in the Shark Bay prawntrawl fishery, Western Australia. Fish. Res., 58: 349-365.

Christian, P. and Harrington, D. (1987). Loggerhead turtle, finfish and shrimp retention studies on four excluder devices (TEDs). In: Proc. Nongame and Endangered Wildlife Symposium, 8-10 September 1987, Georgia DNR, Social Circle, GA, pp. 114-127.

Isaksen, B., Valdemarsen, J.W., Larsen, R.B. and Karlsen, L. (1992). Reduction of fish by-catch in shrimp trawl using a rigid separator grid in the aft belly. Fish. Res., 13: 335-352.

Larsen, R.B. (1996). Experiments with a new, larger type of fish/ shrimp separator grid with comparisons to the standard
Nordmøre-grid. In: ICES CM 1996/B:1, Report of the study group on grid (grate) sorting systems in trawls, beam trawls, and seine nets, Woods Hole, Massachusetts, 13-14 April, 1996, pp. 68-80.

Madsen, N. and Hansen, K.E. (2001). Danish experiments with a grid system tested in the North Sea shrimp fishery. Fish. Res., 52: 203-216.

Renaud, M., Gitschlag, G., Klima, E., Shah, A., Koi, D. and Nance, J. (1993). Loss of shrimp by turtle excluder devices (TEDs) in coastal waters of the United States, North Carolina to Texas: March 1988-August 1990. Fish. Bull., 91: 129-137.

Riedel, R. and DeAlteris, J. (1995). Factors affecting hydrodynamic performance of the Nordmøre grate system: A bycatch reduction device used in the Gulf of Maine shrimp fishery. Fish. Res., 24: 181-198.

Rogers, D.R., Rogers, B.D., de Silva, J.A. and Wright, V.L. (1997). Effectiveness of four industry-developed bycatch reduction devices in Louisiana's inshore waters. Fish. Bull., 96: 552-565.

Rulifson, R.A., Murray, J.D. and Bahen, J.J. (1992). Finfish catch reduction in South Atlantic shrimp trawls using three designs of by-catch reduction devices. Fisheries, 17: 9-19.

Saila, S.B. (1983). Importance and assessment of discards in commercial fisheries. FAO Fish. Circ. No. 765, 62 pp.

Watson, J. (1989). Fish behavior and trawl design: Potential for selective trawl development. In: C.M. Campbell (ed.), Proc. World Symposium on Fishing Gear and Fishing Vessels. Marine Institute, St. Johns, Canada, pp. 25-29. 